\title{
The Female Body as the Site of Male Violence during the Partition of India in Bapsi Sidhwa's Ice-Candy-Man
}

\author{
Arunima Dey ${ }^{1}$
}

\begin{abstract}
This paper on Bapsi Sidhwa's Ice-Candy-Man intends to undertake a comprehensive investigation of various forms of gendered violence during the partition of India. An analysis of the central female figure of Ayah underscores how acts of abduction and rape use woman's sexuality as a tool to articulate religious/national enmity. Moreover, the paper will claim that Ayah's abduction can be read as a punishment for her lack of adherence to cultural norms, which was expected from women during partition period, thereby highlighting that women's bodies were (and continue to be) under patriarchal surveillance and regulation, and those who fail to abide by societal rules are inevitably discarded. Next, I intend to explore the effective use of female agency and solidarity in the novel as a means to counter male violence and subjugation. Furthermore, I will comment on the treatment of abducted/raped women by the patriarchal state to expose the social reality post partition where victimised women, due to their altered position as contaminated sexual beings, were ostracised by society. In essence, by investigating gendered violence during partition followed by continued societal victimisation of the female survivors, this paper will highlight how Sidhwa's novel contributes to a thus far silenced gynocentric reading of partition history.
\end{abstract}

Keywords: Bapsi Sidhwa, Ice-Candy-Man, violence against women, the partition of India, South Asian feminism.

\section{[es] El cuerpo femenino como ubicación de la violencia masculina durante la partición de India en Ice-Candy-Man (1988) de Bapsi Sidhwa}

Resumen. Este artículo sobre Bapsi Sidhwa's Ice-Candy-Man apunta a ofrecer una investigación general sobre varias formas de violencia de género durante la partición de India. El análisis de Ayah. el personaje principal femenino, subraya el hecho de que actos de rapto y violación utilizaron la sexualidad de la mujer para intrumentalizar una enemistad nacional y religiosa. Además de esto, este artículo propone que el rapto de Ayah puede ser interpretado como un castigo por su falta del compromiso con las normas culturales esperado de las mujeres durante el periodo de partición. Pone de manifiesto que el cuerpo de la mujer estaba (y sigue estando) bajo la supervisión y regimentación patriarcal, por lo que los que no se someten a las reglas social son inevitablemente descartados. A continuación, querría explorar los usos efectivos de la mediación y solidaridad femenina en la novela como forma de contrarrestar la violencia y subyugación sexual. Además, hablaré sobre el trato de las mujeres raptadas/violadas por el estado patriarcal para así descubrir la realidad social de la post partición, en donde las victimas eran repudiadas por haber quedado como seres sexuales contaminados. En suma, a través del estudio de la violencia de género durante la partición y la continuada victimización social de los supervivientes, este trabajo quiere resaltar como la novela de Sidhwa contribuye a una lectura ginocéntrica de la historia de la partición que hasta ahora estaba silenciada.

Palabras clave: Bapsi Sidhwa, Ice-Candy-Man, violencia contra la mujer, la partición de la india, feminismo del sureste asiático.

1 Visiting Researcher, Cornell University

ORCID: 0000-0002-9332-0323

E-mail: arunimadey@usal.es 
Contents. 1. Introduction. 2. Female Sexuality and Gendered Violence during the Communal Riots of Partition. 3. Countering Patriarchal Victimisation with Female Agency and Solidarity. 4. Society's Treatment of the Rescued Victims of Rape/Abduction in the Aftermath of Partition Violence. 5. Other Manifestations of Gendered Violence during Partition Period. 6. The Relevance of the Novel's Title. 7. Conclusion.

How to cite this article: Dey, A. (2018) The Female Body as the Site of Male Violence during the Partition of India in Bapsi Sidhwa's Ice-Candy-Man, in Complutense Journal of English Studies 26, $27-45$.

\section{Introduction}

Bapsi Sidhwa's Ice-Candy-Man (1988) exemplifies how women's bodies, reduced to the status of a mute token, become the primary targets of horrific violent acts during ethnic warfare between two communities of men. The predominance of gendered violence during the Indian partition ${ }^{2}$ was due to the fact that attacks on women were symbolic of attacking the honour and purity of the religion/country to which the women belonged. This symbolic interpretation of material bodily harm led to two forms of violence against women. The first form of violence was inflicted on women by men of the other religious community to humiliate and degrade the enemy religion and nation. Conversely, the second form of violence constituted of male family members killing their women or forcing them to commit suicide in order to safeguard familial and ethnic purity from getting contaminated by the other religion. In this context, Sidhwa's novel focuses on the first form of violence. To elaborate, through the character of Ayah and Hamida, the depiction of rape and abduction followed by the rescue and rehabilitation of the victimised women in Sidhwa's novel allows one to decode various forms of religion-incited patriarchal ideology operative during partition era that effectively debunked the reality of women as individuals and turned them into mute signs as deemed appropriate by the male-dominated nation state and society. Moreover, Ice-Candy-Man reveals how apart from the forced silence imposed on the stories of women's abduction and rape, the author underscores the difficulty of bringing forth rape narratives to light because language itself fails to articulate these abominable incidents while keeping the dignity of the victim intact. Hence, in this paper, my aim is to engage in a gynocentric criticism of gendered violence during partition riots, which has been intentionally neglected by the hegemonic male-centric versions of partition.

Sidhwa's Ice-Candy-Man (1988), subsequently published in the US as Cracking $\operatorname{India}^{3}$ (1991), is the first Pakistani Anglophone novel that not only narrates the story

2 The partition of India accompanied India's attainment of independence from the British Empire on 15 August 1947. As the British departed their largest colony after over two hundred years of colonisation, British India was divided into India, and West and East Pakistan. The partition occurred on religious grounds where Hindus and Sikhs were assigned India while Muslims were allocated the newly made Islamic nation of West and East Pakistan. The Indian partition witnessed large-scale riots, which were informed by murders, lootings, burnings, rapes and abductions.

3 The movie adaptation of the book titled Earth (1998) was directed by Indian Canadian Deepa Mehta. Mehta claimed that the film "hoped to understand why war is waged and why friends turn enemies, and why battles are invariably fought on women's bodies" (qtd. in Parmar 2007: 208). However, unlike the book, the movie ends with the climactic scene of Ayah's abduction and refuses to tell the story further, thereby reemphasising the very absence in official history regarding issues of violence against women and the lives of the victims thereafter. At 
of the partition of India, but also testifies to the multiple expressions of gendered violence that formed the crux of the ethnic genocide of partition. The novel has been claimed to be "one of the finest responses to the horror of the division of the subcontinent" that casts the reader as a "witness who must now share the pain, the blame, the guilt" of the horrific event (Rushdie qtd. in Roy 2010: 64; Bahri 1999: 228). Another perspective is given by Nadia Butt who asserts that Sidhwa "offers a fine combination of ... fact and fiction to express the emotional impact" of partition by "recall[ing] the pain of old wounds so that they may finally be healed" (2015: 83, 74). Furthermore, by writing most of the novel in the present tense, the author "repeatedly situates violence right here, right now," thereby underlining "the ubiquity of violence" (Stokes 2008: 56). In fact, Sidhwa, in her own words, states:

$[\mathrm{M}] \mathrm{y}$ intention was to write about Partition because very little had been written about it. There are certain images from my past which have always haunted me ... Although I was very young then, I saw chance killings, fires, dead bodies. These are images which have stayed with me ... This hostility needs to be dealt with. (qtd. in Rastegar 2006: 26)

When one reads Ice-Candy-Man/Cracking India, it is evident that Sidhwa does achieve what she was aiming to articulate through her storytelling. For this purpose, she uses a seven year old girl narrator called Lenny who belongs to the Parsi ${ }^{4}$ community. Parsis are a numerically minute though affluent community in India who held a neutral position during the partition riots between Hindus, Sikhs and Muslims. Despite her class privilege, by virtue of her being a female who is physically disabled due to polio, Lenny occupies a marginalised position in society. Even though Lenny is young, her marginalisation is a fact that she is nonetheless acutely aware of. Lenny's own subject position at the fringes of society makes her compassionate and capable of understanding the suffering of those who are neglected by the ones who occupy the centre, i.e., men and official history. Hence, "Lenny, from behind this veil of marginality, offers a uniquely subaltern view of the bloody birthing of Pakistan," and in effect, helps one "rescue all these lost narratives" about women (Bharucha 1996: 132; Kabir 2005: 184). In other words, Lenny's authority as a narrator incorporates the female voices that fill the gaps within male-centric historical narratives. Moreover, Lenny's unrelenting curiosity reveals "culturally accepted code of censorship in which women who 'betray' the ideologies of purity and honour are simply obliterated from memory" (Das 1995: 188). Furthermore, it can be claimed that "Sidhwa's attention to the spectatorial materiality of bodily violence and pain through the child's vision of heightened perception begins to address the problem of how to represent, ethically, the sexualizing of bodily violence that characterized Partition" (Daiya 2002: 234). In this manner, Ice-Candy-Man/Cracking India becomes

\footnotetext{
best, the film is a diluted and simplified version of the multiple layers of physical and psychological gendered violence depicted in the novel. The most problematic aspect of the movie is that the film turns Ayah into an object of desire, which permits a voyeuristic sexualisation of her body. In fact, with her abduction, Ayah goes from an "erotic spectacle" to a "passive victim," which deviates largely from the strong-willed Ayah in the book (Uraizee 2010: 26). Nonetheless, the film was critically acclaimed and though lacking in several aspects, the film did succeed in bringing forward the horrors of the Indian partition to the international audience about which the rest of the world beyond South Asia knows very little about.

4 Parsis are followers of Zoroastrian faith originally from Iran/Persia.
} 
a "quasi-historical" text (M. Mitra 2008: 24). Therefore, by using a female child narrator as her mouthpiece to tell the gory story of partition, Sidhwa articulates not just the violent legacy of formation of two postcolonial nations, but also exposes how exploitative patriarchal rubric governs everyday life and the process of nation building.

\section{Female Sexuality and Gendered Violence during the Communal Riots of Partition}

The novel begins just months before the partition of India in the city of Lahore ${ }^{5}$ where prepubescent Lenny is under the charge of her Ayah, a young Hindu woman named Shanta ${ }^{6}$. Ayah is shown to be a strong woman who exercises autonomy over her life and her multi-ethnic group of suitors; Lenny observes: "[T] the group around Ayah remains unchanged. Hindu, Muslim, Sikh, Parsee are, as always, unified around her" (Sidhwa 1988: 97). Hence, one can assert that Ayah's flock of friends, which is comprised of all faiths and religions from undivided India, resonates a sense of communal harmony. In other words, "the Hindu Ayah's multi-confessional group of lovers represents a pre-partition pluralist idyll," which is now seen as an irretrievable past in the postcolonial memory of the divided nation (Bernard 2010: 16). Moreover, this group also functions as a "barometer" that shows the changing political scenario in the country reflected in the "alterations that take place in the nature, number, mood and tenor of this circle" (Roy 2010: 68). Amongst this secular group, the most prominent suitors of Ayah are Masseur and Ice-candy-man, who are both Muslims. Furthermore, Ayah is projected as one with abundant sensuality and beauty, which makes her extremely attractive to men:

The covetous glances Ayah draws educate me. Up and down, [men] look at her. Stub-handed twisted beggars and dusty old beggars in crutches drop their poses and stare at her with hard, alert eyes. Holy men, masked in piety, shove aside their pretences to ogle her with lust. Hawkers, cart-drivers, cooks, coolies and cyclists turn their heads as she passes, pushing my pram with the unconcern of the Hindu goddess she worships. (Sidhwa 1988: 3)

The lines indicate that though she is sexually desired by men, Ayah is not reduced to a fetishised commodity, thereby "[c] hallenging the pervasive entanglement of 'desired' woman with 'powerless woman"' (Stokes 2008: 62). In fact, when men compete for Ayah's attention, she is the "judge, not prize" (Stokes 2008: 64). On similar lines, Jacquelynn Kleist argues that Ayah "exudes a degree of control, able to uniquely influence the men around her" (2011: 73). Moreover, not only does Ayah exercise freedom of movement, which was seldom afforded to women during partition period, she also channels her feminine agency to her advantage and is able to regulate unwanted attention from men such as the Ice-candy-man. As Lenny observes in the novel: "Things love to crawl beneath Ayah's sari. Ladybirds, glow-worms, Ice-can-

\footnotetext{
Post partition, Lahore became a part of Pakistan.

Throughout the novel, Shanta is referred to as Ayah, meaning 'nanny'. The word Ayah belongs to the group of terms that is unique to South Asian English.
} 
dy-man's toes. She dusts them off with impartial nonchalance" (Sidhwa 1988: 1819). In essence, Ayah is portrayed as

the magical goddess of racial harmony, the locus of convergent desire, the border terrain that neutralizes ethnic or religious difference. Surrounded by her circle of admirers in the park ... Ayah reigns ... over an ethnic spectrum of working-class males: cooks, gardeners, masseurs, traders, butchers, wrestlers, and Ice-CandyMan. (Hai 2000: 398)

The aforementioned quotation indicates that Ayah's "chocolate chemistry" endows her with the ability to partake actively in performance of her sexual desires with men from varied cultural and religious backgrounds (Sidhwa 1988: 18). By doing so, she challenges patriarchal codes of behaviour by rejecting notions of chastity and curbing of one's bodily desires as expected from women by society. Lenny further narrates: "[S]he has a rolling bouncy walk that agitates the globules of her buttocks under her cheap colourful saris and the half-spheres beneath her short sari-blouses" (Sidhwa 1988: 3). These lines imply that not only was Ayah aware of her captivating sensuality, but also didn't bother to adhere to the normative concept of feminine modesty. In fact, it can be claimed that "the subversive effects of Ayah's bodily expression of desire articulate a more permeable and heterogeneous definition of the national imaginary than the narrow, restrictive one that eventually prevails in Pakistan" (Didur 1998: 59). This supposedly rampant sexuality of Ayah that bestows her with power must be controlled within the patriarchal scheme of things. Ayah's abduction, therefore, can be seen as punishment meted out to her because of her unapologetic sexuality, since "[s] exually awakened women affirmed and recognized as such would mean the complete collapse of the [male] authoritarian ideology" (Reich qted. in Punjabi 2012: 253). Hence, as Ayah refuses to follow a chaste and subservient notion of femininity, her supposed insolence is punished by physical abuse and humiliation. This is foreshadowed in the change in Ayah's treatment by her group in the months leading to partition.

As the narrative develops, i.e., as the social environment begins to get charged with increasing communal animosity, where "the secular landscape of Lahore is fragmented into religious enclaves," Ayah gradually begins to lose her autonomy (Bharucha 1996: 137). As Jill Didur notes, when the novel opens, "Ayah/Shanta is able to deflect patriarchal expectations of monogamy and conjugality, [while] after partition, her actions are constrained and her agency and body [are] governed by patriarchal struggles over land and identity" (2006: 68). Moreover, in terms of the physical setting, the secular group that previously gathered at Queen's Park beneath the statue of Queen Victoria, which symbolised the united religions under British rule, now moves to the Wrestler's restaurant. This shift in location dislocates Ayah from the centre of the circle literally and symbolically, highlighting her systematic loss of authority. With the growing Hindu/Muslim tensions, the group initially resists segregations, but ultimately fails to remain united. To underscore this aspect succinctly, Lenny notes: "I become aware of religious differences. It is sudden," further claiming that "[o]ne day everyone is themselves - and the next day they are Hindu, Muslim, Sikh, Christian. People shrink, dwindling into symbols. Ayah is no longer just my all-encompassing Ayah - she is also a token" (Sidhwa 1988: 93). Hence, Lenny's words indicate that 
the narrowing and shoring up of community identity diminishes the vitality and complexity of social relations in the community. Ayah and the others reconfigure their self-presentation when they sense their interests are in danger of being marginalized - or conversely, elevated to a privileged position - within the shifting relations of power pervading the country. (Didur 1998: 60)

Exemplifying the aforementioned lines, Lenny informs the reader that while Ayah starts conducting prayer rituals for her Hindu Gods and the Muslim cook Imam Din asks for Friday afternoons off to attend Jumha prayers ${ }^{7}$, Ice-candy-man begins to show resentment towards his non-Muslim friends such as the Sikh zoo attendant Sher Singh. Furthermore, Lenny's observation suggests how during partition period, people's individual/cultural/social identities were subsumed by the sole factor of their religion. Hence, the "all-encompassing Ayah" is now reduced to a "token" by the all-encompassing obsessive demonstration of religion fidelity (Sidhwa 1988: 93). In effect, Ayah "no longer seems to control the surveillance of her body; she becomes vulnerable to the penetrating masculine gaze" (Muirhead 2002: 55). Therefore, it can be said that Ayah's feminine agency is unable to restrict the growing nationalist discourse that redefines her body in communal colours. As Lahore begins to burn with religious frenzy, "it becomes apparent that her heterogeneous experience of day to day life is being undermined" by the escalating religious patriarchal society (Didur 1998: 60). Furthermore, as a woman, "[t] he value of her reproductive body in its nationalist signification as mother to future generations supersedes the quotidian flirtations of sexual desire" (Muirhead 2002: 80). In this manner, the vibrancy of Ayah's sexuality, and as an extension, her identity, is reduced to her reproductive capability.

Interestingly, one must note that "Lenny's ayah, the chocolate-brown, desirable, round-cheeked, full-breasted woman, is symbolic of the Indian earth" (Bharucha 1994: 81). To be specific, Ayah symbolises the bountiful unified India (under whose shade people of all ethnicities and cultures flourish and grow), which is threatened and eventually ravaged by communal fanaticism. Here, one may argue that by associating the female body to nation, Sidhwa reasserts the patriarchal concept of the feminised country that must be protected from the onslaught of the outsider. On the contrary, I find that by connecting Ayah with undivided India, the novel highlights the beauty of a wholesome and integrated India through Ayah's vitality. Hence, in this context, "the defiling of [Ayah] can be seen as reflecting symbolically the despoiling of the country" (Purohit 2012: 451). Furthermore, though she is a Hindu, she never emphasises on this aspect (until much later), which makes her a multiethnic site that permits harmonious intermingling of all faiths and beliefs. In fact, on the occasion when Ice-candy-man questions Ayah whether she is a Punjabi, Ayah "warily" responds, stating: "For the most part" (Sidhwa 1988: 29). Ice-candy-man then questions her as to why then she doesn't wear salwar kameez ${ }^{8}$, which is typically worn by Punjabi women. Ayah replies claiming that nannies who wear salwar kameez earn less money than sari-wearing Goan ${ }^{9}$ housemaids, who are presumed to be more

\footnotetext{
Jumha is Arabic for 'Friday'. Jumha prayers, therefore, refer to Islamic Friday prayer sessions.

8 Salwaar kameez is a predominantly North Indian women's attire that consists of a loose-fitting long top worn with drawstring harem pants.

9 In all likelihood, Goan housemaids signify Christian Indian nannies from the Western Indian state of Goa.
} 
qualified for the job. This incidence reveals Ayah's resistance of Ice-candy-man's attempt to stratify her identity as solely Punjabi. Furthermore, Ice-candy-man's effort to define Ayah by her ethnic identity foretells his abduction of her, which is validated by the same aspect. In essence, while national borders are drawn and contested, Ayah's individuality does gradually get codified solely based on her religious identity. Ayah ceases to be "the cathexis for a temporary multicultural, multireligious sodality," and finally, her bodily borders are violated where "her sex [becomes] an invitation to settle scores" (Bahri 1999: 223). In fact, the same woman who was able to regulate talks amongst her suitors about religious rivalry by threatening to deny them of her company falls prey to fanatic religious violence.

This brings the discussion to Ayah's abduction. I begin by asserting that at times of ethnic genocide, one witnesses the "metamorphosis" of women into "possessions; living objects on whose soft bodies victors and losers alike vent their wrath, enact fantastic vendettas, celebrate victories" (Sidhwa 2008: 49). In effect, during fratricidal wars, violence against women can be read as "the most pervasive form of abuse: a universal phenomenon that cuts across all divisions of class, race, religion, age, ethnicity, and geographical region" (Pickup 2001: 11). Moreover, referring specifically to abduction of women during partition, Veena Das claims that this violent act can be seen as "simply the other side of the matrimonial dialogue between men, in which women are exchanged as signs" (1995: 186). Here, it is crucial to mention that among the two aforementioned Muslim suitors of Ayah, Masseur, who Ayah chooses as her beloved, represents the pacifist ideology of communal belonging, while Ice-candy-man can be associated with the frenzied mob who aims at aggressively proving one's religious supremacy over another. In this context, right before Ayah's abduction, Lenny finds Masseur's body neatly hacked in a gunny sack (Sidhwa 1988: 174). Hence, one must note that Masseur's death symbolises the erasure of pacifist values in the face of the violent uprising of communal hatred during partition. Sidhwa does not reveal who killed Masseur, though it can be assumed that Ice-candy-man, on being rejected by Ayah, who favoured Masseur over him, murders his fellow Muslim out of jealousy and anger. This is interesting because in this case, violence is not enacted based on communal animosity, but personal vendetta.

Before I comment further on Ayah's abduction, I must briefly summarise the scene: During partition riots in Lahore, a Muslim mob, which includes Ice-candyman, arrives at Lenny's bungalow demanding the family to hand over the Hindu Ayah. Imam Din, the Muslim cook, commits blasphemy by lying to the mob, swearing that Ayah has left Lahore. Imam Din lying under oath to protect Ayah reveals how "ethnic identities ... were often ethically appropriated and deployed to interrupt political violence" (Daiya 2002: 228). The mob also demands for the Hindu gardener Hari, and the reader is informed that Hari has now become Muslim (rechristened as Himat Ali). The mob then asks to see the physical proof of his conversion, which leads to Hari/Himat Ali showing his newly circumcised penis to the mob as a concrete validation of his new Muslim identity. While the mob vulgarly scrutinises Hari/ Himat Ali's penis, Ice-candy-man seeks out Lenny and tricks her into telling him where Ayah is hiding by assuring Lenny that he would protect her beloved Ayah. This leads to Lenny, with her "truth-infected" tongue, unwittingly betraying Ayah (Sidhwa 1988: 184). Once Ayah's hideout is revealed, the mob rampages through the house to find Ayah. The horrific scene is described as follows: 
They drag Ayah out. They drag her by her arms stretched taut, and her bare feet - that want to move backwards - are forced forward instead. Her lips are drawn away from her teeth ... Her violet sari slips off her shoulder, and her breasts strain at her sari blouse stretching the cloth so that the white stitching at the seams shows. A sleeve tears under her arm.

The last thing I noticed was Ayah, her mouth slack and piteously gaping, her dishevelled hair flying into her kidnappers' faces, staring at us as if she wanted to leave behind her wide-open and terrified eyes. (Sidhwa 1988: 183-184)

Ice-candy-man's abduction of Ayah is a not simple case of a man committing violence against a woman belonging to the enemy religion. On the contrary, Ice-candyman uses communal violence "to settle personal scores" (Roy 2010: 71). Ice-candyman fixates on the Hindu aspect of Ayah to "[facilitate] her objectification and violation in order to fulfil his desire for her. This process ... suppresses the historicity of her body in order to construct it as ethnic," thereby turning her body into "a site of sexual and cultural transaction" (Daiya 2002: 230). In essence, Ice-candy-man's actions are those of a jilted and jealous lover who uses the ethnically charged situation of partition to extract revenge from Ayah for rejecting him by narrowing down on the Otherness of her religion.

I previously noted that Hari/Himat Ali's conversion to Islam was verified through his bodily modification. To elaborate, Kavita Daiya claims that "Hari's conversion probably constitutes the humiliating, symbolic emasculation of Hindu men for the mob, as well as legitimizes his presence in the new nation-state Pakistan created for Muslims" (2002: 225). Such an option is not available to Ayah. This is because women's bodies lack any definite markers that can identify them as belonging to a particular religion. Furthermore, women do not have a direct relationship with religion because their religious identity is defined by their fathers/husbands. However, despite women's indirect relationship with religion, familial/communal honour is tied to women's sexual purity. Since the abducted and raped woman is "symbolic of crossing borders, of violating social, cultural, and political boundaries," she can no longer "be the vehicle of the familial metaphor that enables the narration of the nation" (Menon and Bhasin 1998: 20; Ray 2000: 135). Hence, post her abduction, Ayah's persona diminishes into silence.

In this manner, due to her socially altered position after her abduction and presumed gang-rape, the previously all-encompassing Ayah, who formed the social glue that held together various strands of ethnic diversities, is now perceived as a sexually tainted being and is cast out of the social fabric of the new nation. In fact, "[ $t]$ he inevitability of rape leaves woman with the 'choice' of committing suicide so that she can be accommodated within the narrative of the nation as a legitimate and pure - albeit dead - citizen," or fall victim to sexual predators and then suffer social death (Ray 2000: 135). In this context, men can be considered "sexual terrorists" who "utilize rape as a weapon of revenge" against women of the enemy religion to denote "an infringement on other men's property," which in effect, makes rape a form of dialogue between men "about an invisible woman" (Allen 1986: 41). Hence, Ayah's abduction and rape echo the predicament of thousands of women who were "caught in the crossfire between rampant patriarchy and callous colonialism" during partition (Bharucha 1996: 137). Moreover, here I must reiterate that Ayah never particularly 
focussed on her Hindu identity. Similarly, Masseur is portrayed as a humanist. Both Ayah and Masseur do not outwardly reject their religion, but treat it as one of the aspects of their identity. Though they "redefine religious identification as an ethical openness to the other," this invariably results in their failure "to perform the expected and idealized roles of nationalist, patriotic, and religious subjects," since "neither desires a particular national or religious identity" (Majithia 2015: 17). Therefore, at a time when bloodlust for the religious Other reigns supreme and one is defined solely as Hindu-Indian or Muslim-Pakistani, those who do not adhere to such nation$\mathrm{al} / \mathrm{ethnic}$ identification are either eliminated (Masseur is killed) or punished (Ayah is abducted and raped).

Ayah's abduction reveals that during the ethnic genocide of partition, violence against women was "at once the most visible, and the most repressed, index of the social, cultural and familial fragmentation that constituted Partition" (Kaul 2001: 11). Furthermore, one can assert that "[n]ationalism gives birth to its double - communalism ... by making the bodies of women the surfaces on which their text of the nation is written" (Das 2006: 46). In other words, communalism gets deployed for nationalist interests that permit dehumanising acts on women's bodies as a perverse way of imprinting man's sovereignty. Similarly, it can be claimed that "women, nation, religion, history are all welded together in seamless fantasies of sexual violence" (Punjabi 2012: 246). In fact, as noted previously, in the novel, as communal tension rises in Lahore, "the signification of Ayah's body subtly shifts from sexually attractive femininity to vulnerable Hindu femininity," which finally culminates in her abduction and rape (Stokes 2008: 64). Moreover, as Didur claims: "If Ayah's [initial] bodily experience of desire as agency represents a challenge to conservative-nationalism, it is this same site that [subsequently] becomes the focus of scrutiny in the struggle for power that unfolds" (1998: 60). In essence, at the time of partition violence, Ayah's once pluralistic identity becomes a vulnerable "porous frontier" that is crossed without her consent (Loomba 2015: 160). Therefore, not only is Ayah's body reduced to a symbol within patriarchal power-play of communal nationalism, this aspect also annihilates her individual multi-faceted identity as a human.

An analysis of Ayah's abduction remains incomplete without addressing Ayah's fate post this horrific incident. Here, it is essential to realise that universally, raped bodies always have and continue to be seen as shamed bodies. In this context, Peiling Zhao observes that "[a] nation, treated as a living soul ... also feels shame - disgrace, dishonor, and humiliation ... and consequently it changes the bodies of its subjects to dissolve the national shame" (2013: 179). Similarly, after partition, in the case of India and Pakistan, the ideology of national honour and pride was reflected through the nations' women's sexual purity. Hence, when women were raped, their now contaminated bodies became indicative of the humiliation of their respective nations, "thereby literally and metaphorically marking the women's bodies as outside of national membership" (N. Mitra 2013: 198). In order to exemplify the same, after her abduction, Ayah, apart from certain sporadic instances, disappears from the narrative. Ayah's shame, henceforth, is marked through her silence and absence.

Regarding Ayah's silence and absence, Ambreen Hai in her essay "Border Work, Border Trouble" (2000) claims that Sidhwa's text reasserts the very silences that are created by official history, thereby complying with the nationalist viewpoint that stories about raped and abducted female bodies do not fit into the scheme of na- 
tion-building. However, Hai ignores the fact that by refusing to narrate Ayah's rape story, the novel "points to the (im)possibility of completing the history of Partition with 'first hand' testimonial or fictional accounts by underscoring the 'unnarratable' quality of 'abducted' women's experience" (Didur 2006: 69). In fact, Ayah's silence reflects the tremendous discomfort that official historical narratives show in acknowledging this aspect of partition violence, since "an admission of violation, [is] tantamount to an admission of public defeat for the community whose woman has been violated. Hence, the ongoing tyranny of silence" (Bahri 1999: 220). Moreover, intentionally not narrating Ayah's rape does not indicate Sidhwa's hesitancy to reveal the gory face of violence against women, rather it shows her acute awareness of not turning the dreadful act into a voyeuristic narrative. In this manner, Sidhwa avoids "inflicting a gaze of 'erotic fascination' upon the body of the survivor" (Stokes 2008: 59). Hence, "by placing rape outside the text's narrativity," Sidhwa's novel "represents the inarticulability of extreme horror" of gendered violence during partition (Subramanian 2013: 88). On similar lines, Deepika Bahri eloquently captures the silence that surrounds rape narratives:

The deeply entrenched social proscription against the speaking of this most invasive and intimately experienced trauma makes it doubly unspeakable - it is unspeakable not only in that its content is untranslatable into language; it is literally unspeakable in that it may not be spoken of for fear of a social "death." (1999: 219)

Bahri's statement justifies why Ayah refuses to speak. This is because Ayah suffers "a trauma that is both psychological and psycho-social" (Bahri 1999: 221). Moreover, in Ayah's silence, one can find her determination to resist reliving her violation by refusing to remember and articulate her traumatic memories.

After her abduction, Ice-candy-man makes Ayah a prostitute at Hira Mandi ${ }^{10}$. In this manner, Ice-candy-man not only violates Ayah's body, but also uses it as a means of opportunistic financial gain. Here, one may note that the transformation of Ayah as a prostitute, which casts her in a subservient position, can be interpreted as a punishment for her daring to defy sexual codes of female chastity in undivided India. Therefore, after her abduction, punishment for previously exercising sexual freedom continues in the form of Ayah's objectification and exploitation at the hands of her sexual predator. In essence, "Sidhwa locates Ice-candy-man's abuse of Ayah within a broad framework of gender-based oppression, within which women who deviate from the (always unstable) confines of acceptable femininity are subject to violent abuse by those closest to them" (Stokes 2008: 68). This further reflects "on the convergence of desire and violation, of Eros and Thanatos in Ice-Candy Man's opportunistic appropriation of Ayah" (Bahri 1999: 230). Moreover, on discovering the rescue mission undertaken by the two governments for abducted women, Ice-candyman promptly marries Ayah, and she is rechristened by him as Mumtaz ${ }^{11}$. According

10 Hira Mandi translates to 'Diamond Market' from Hindu/Urdu. This is the red-light district of Lahore. The word diamond is a euphemism used to refer to the prostitutes.

11 Ayah's rechristened name Mumtaz is borrowed from the Mogul emperor Shah Jahan's most beloved wife Mumtaz Mahal. After her death, Shah Jahan built a white marble mausoleum as her final resting place. This mausoleum is the most popular architectural wonder of India named Taj Mahal in the city of Agra. The Taj Mahal is universally considered a symbol of everlasting love. Hence, by renaming Ayah as Mumtaz, Ice-candyman further heightens the perversity of his supposed love. 
to Katherine Stokes, when Ice-candy-man gives Ayah a new name, he "linguistically mark[s] his violent reinvention of the woman" (2008: 68). This renaming act is yet another symbolic marker of the annihilation of her previous identity.

In effect, by means of constant violation, firstly by Ayah's abduction and rape followed by her being forced into prostitution and marriage with her abductor-rapist along with her being rechristened as a Muslim, Ayah's body "acquires its own clandestine history of alterity" (Feldman 1991: 80). In fact, when Lenny finally meets Ayah after her abduction, she narrates: "Where have the radiance and the animation gone? Can the soul be extracted from its living body?" (Sidhwa 1988: 260). Lenny's words highlight that after being robbed of her dignity and agency, Ayah appears less human and more puppet-like. Lenny further notes that Ayah is dressed as a courtesan and her "wideopened" eyes appear "vacant," highlighting how with her individuality drained out, Ayah is now simply an empty physical shell (Sidhwa 1988: 260). In effect, Lenny's observation suggests that Ayah appears like a ghostly figure: "Dead while living and exiled from the familiar in terms of home, labor and love, [Ayah's] eyes provide the 'unsayable' alternate history, the 'unsayable' like the 'dead' writing history with their absence" (Subramanian 2013: 91). The only words Ayah utters are "I want to go to my family" to which she adds: "Whether they want me or not, I will go" (Sidhwa 1988: 261, 262). These lines suggest that despite knowing her now altered social position as a sexually impure woman, she chooses to leave Lahore and go to her family in India.

\section{Countering Patriarchal Victimisation with Female Agency and Solidarity}

Ayah attempts to exercise her autonomy and agency when rejects the socially acceptable position that she occupies as a wife by refusing to stay with her rapist. By choosing to go home where her membership in society is likely to be contested due to her position as a raped woman, she refuses to accept her ejection from the newly formed nation across the border. Hence, Ayah's decision to return to social life with her family in India instead of accepting a domestic life with Ice-candy-man in Pakistan reveals how "she troubles and rejects both discourses of suicide and nationalism" (Daiya 2008: 74). To elaborate, Ayah rejects the discourse of suicide by refusing to kill herself for the sake of familial/national honour, and by choosing to be integrated back into the familial unit. Similarly, since nationalism, among other things, is founded on the idea of the ideal family, which operates as a microcosm of the nation, Ayah rejects the discourse of nationalism when she leaves her rapist-husband Ice-candy-man. This reflects Ayah's strength of character and her attempt at reinventing her agency.

Apart from permitting Ayah the ability to reclaim her agency, Sidhwa also snatches away the victimiser's power in the end. As the novel unfolds, Ice-candy-man transforms from a lover/friend to a "monster" to a "pathetic character" (Rastegar 2006: 31). In fact, the reader finds that as Ayah departs for Amritsar (India), Ice-candy-man is reduced to a weeping mess. However, his tears are not a sign of his repentance, but rather his dejection at the loss of his plaything, i.e., Ayah. The novel ends with Ice-candy-man following Ayah across the border to India, implying that even though the ethnic genocide has now ceased post partition, the threat of gendered violence continues.

Here, it is important to note that it is not just Ayah who rebels against her forced victimhood. In the novel, it is evident that besides Ayah, Sidhwa endows several other female characters with authority. For instance, it is Lenny's Godmother who 
confronts Ice-candy-man about his crimes: "You permit [Ayah] to be raped by butchers, drunks, and goondas ${ }^{12}$ and say she has come to no harm?" (Sidhwa 1988: 248). Godmother further asserts: "You have permitted your wife to be disgraced! Destroyed her modesty! Lived off her womanhood! ... You are the son of pigs and pimps" (Sidhwa 1988: 248). In fact, Godmother's interrogation of Ice-candy-man runs for several pages in the novel where his initial attempt at weakly-worded self-defence is gradually silenced in its entirety by Godmother's truth-infused hard-hitting words. This is a powerful scene because it is one of the few instances in partition literature where the guilty is not only held accountable, but is also shamed into silence, thereby made to face a similar fate as that of his victim. Here, it is interesting to note that Godmother's "femininity (as represented by motherhood and sexuality) is distinctly neutered," which can imply that the text either deliberately or unwittingly suggests that power can only be asserted in the absence of feminine sexuality (Muirhead 2002: 74). Nonetheless, apart from highlighting Godmother's ability to rescue Ayah from the clutches of Ice-candy-man, the reader is informed that Lenny's mother and aunt are stealing petrol to help families migrate across the border. In this manner, Lenny's female relatives actively engage in rescuing and rehabilitating abducted women and saving people from religious violence.

At this point, it is crucial to once again address Hai's essay "Border Work, Border Trouble" that gives a Marxist reading of the novel and claims that "the body of a female Hindu domestic servant [is] the only site upon which the unspeakable can be permitted to happen" (2000: 391). Hai further adds that Ayah becomes "a tool to emphasize the goodness of the ethnically neutral and upper-class Parsee women who volunteer to save her and others like her" (2000: 391). Moreover, Hai reads Godmother's chastisement of Ice-candy-man as "the power of speech" given to only "the self-righteous upper-class rectifier of violence" (2000: 400). In this context, I find Hai's analysis forcefully critical of the novel's potential and aim. As opposed to Hai, I claim that Sidhwa's novel is a potent example of female solidarity that debunks class and religious borders. Hai paints a picture in black and white where the upper class Parsi women are entirely privileged, while the lower class woman is completely victimised. On the contrary, women in Sidhwa's novel partake in "a female version of nation making," as opposed to the patriarchal idea of the nation, which is defined by "brutality and irrationality," by revealing how her female characters "pick up the pieces and begin to unify and mend broken bodies and a cracked country" (Stampfl 2010: 308). Furthermore, I have already explained that despite being raped and abducted, Ayah still engages in decision-making regarding her life. Similarly, one must remember that though Lenny belongs to the upper class, she is marginalised due to her disability. Lastly, upper class women too are shown to be victims of everyday patriarchal order in the novel. To elaborate, depicted as a powerful woman who uses her class privilege and neutral religious identity to rescue raped/abducted women during partition, Lenny's mother is a victim of gendered violence at home. In one episode, Lenny hears her mother say: "No, Jana; I won't let you go! I won't let you go to her!" (Sidhwa 1988: 212). On another occasion, Lenny finds bruises on her mother's body (Sidhwa1988: 212). These instances suggest that not only does Lenny's father cheat on his wife, he also physically assaults her. Here, one can claim that victimised at home, her own familiarity with violence instigates the willingness

12 Goondas is Hindi for 'goons'. 
in her to rescue sexually violated female victims of partition riots. In this manner, Sidhwa demonstrates how what holds all women together is the awareness of their shared violation of their rights and bodies by men, and this instigates the women's compassion towards each other.

\section{Society's Treatment of the Rescued Victims of Rape/Abduction in the Aftermath of Partition Violence}

The narrative informs the reader that a temporary rehabilitation shelter in the neighbouring house is established for raped/abducted women who were recovered by the state post partition. This halfway house is representative of how "women who survived wartime rape often suffered physical damage and were left isolated" (Franco 2013: 78). These women can therefore be called a "disenfranchised class" (Subramanian 2013: 92). Lenny observes that the women in the camp next door "keep to themselves, unobtrusively conducting their lives, lurking like night animals in the twilight interiors of their lairs" (Sidhwa 1988: 189-190). Lenny further adds that at night, she can "hear them wailing, their cries verging on the inhuman" (Sidhwa 1988: 212). In Lenny's description, these women do not speak but cry. This is because the women's "pain does not simply resist language, but actively destroys it, bringing about an immediate reversion to a state anterior to language, to the sounds and cries a human being makes before language is learned" (Scarry 1985: 4). To elaborate, after being dehumanised through severe bodily violence where the women's autonomy is entirely erased, the victims are reduced to wounded animals whose cries have turned inhuman. The women's manic cries are significantly referred to as "inhuman" because the trauma of violence is such that language escapes its purpose of articulation of their violent experience (Sidhwa 1988: 212). Moreover, Lenny notices "a padlock the size of a grapefruit on the gate" of the shelter that makes her think that the place is a "women's jail, even though they look innocent enough" (Sidhwa 1988: 189). In this case, Lenny's assumption is not inaccurate. The camp, which shelters female victims of rape and abduction, ensures that these women are barred from returning unsupervised into society lest they pollute and debunk nation$\mathrm{al} /$ communal honour that is linked to female sexual purity. As defected and shamed bodies, these women are literally locked out of society until the paternalistic government or their male kin decide what should be done with the victims who denote an embarrassing social anomaly to patriarchal state and community. This kind of treatment of abducted/raped female survivors highlight the double victimisation of women who are first physically and psychologically brutalised as tools of fratricidal war, and then socially ostracised by the nation state that refuses to accept rape victims within the social matrix in order to preserve its idea of national/ethnic purity.

In fact, Ayah's disappearance from the narrative is counter-balanced by the appearance of the aforementioned recovery camp next door to reveal not only the widespread and pervading use of rape and abduction during partition, but also to underscore how the victimised women were treated by society and the state. As Ayah vanishes after her abduction, she is replaced by her Muslim counterpart Hamida who was abducted by the Sikhs and was subsequently retrieved from the women's camp and employed by Lenny's mother as Lenny's new nurse. Abducted and raped, Hamida is unable to return to her family because she is now what society considers "a 
fallen woman" (Sidhwa 1988: 214). While Ayah denotes thousands of abducted and raped women, Hamida becomes representative of the victims' predicament thereafter whose condition exposes "the failure of the new nation states to address as well as redress their post-Partition problems" (Roy 2010: 77). While Hamida accepts her socially ostracised situation as her fate, Lenny rejects it, saying that "I've seen Ayah carried away - and it had less to do with fate than with the will of men" (Sidhwa 1988: 214). Furthermore, Lenny's childlike curiosity results in her asking questions to Hamida about her past. These questions, unsurprisingly, Hamida is not just reluctant but unable to answer, thereby reasserting the idea that even remembering the traumatic incident results in a "second violation" of the victim (Gunne and Thompson 2010: 14). Lenny then has a similar discussion with her Godmother who explains her why Hamida cannot return to her family. After hearing her Godmother's explanation regarding Hamida's situation, Lenny observes: "It's monstrously unfair: but Godmother's tone is accepting" (Sidhwa 1988: 215). Here, one may claim that due to the awareness of her own marginalised disabled body, Lenny finds compassion for Hamida "through her recognition of a shared, nonnormative embodiment" (Daiya 2015: 271). In this manner, Lenny scrutinises the concept of sexual contamination and reveals "the way patriarchal nationalist interests produce [abducted/raped women's] identities as polluted" (Didur 2006: 73). In other words, Lenny's refusal to accept the normalisation of the treatment of abducted/ raped women by the nation and society challenges the ways in which the patriarchal state decides who is worthy of being incorporated in the new community of the postcolonial nation.

\section{Other Manifestations of Gendered Violence during Partition Period}

Though ideas such as Ayah's abduction and her predicament thereafter, and Hamida's social castigation are central to the novel, several other instances of gendered violence during partition are abundant in the text. One such instance is when Icecandy-man, who was expecting his relatives to arrive on the train from Gurdaspur (city in present day India), informs the reader: "Everyone in [the train] is dead. Butchered. They are Muslim. There are no young women among the dead! Only two gunny-bags full of women's breasts!" (Sidhwa 1988: 148-149). The mutilation of women's breasts was a common act during partition violence, which suggested destroying the glorified position of women as nurturers. In effect, "[a]s the female body is the locus for reproduction, it becomes a site of immense concern to the male patriarch" (Gunne and Thompson 2010: 8). Furthermore, "[d]etached from whole bodies, the sexed body parts are powerful testimony to the dehumanization of women and their reduction to ghastly currency in an exchange determined by the rules of men" (Bahri 1999: 224). In fact, the mutilated breasts become a form of dialogue between men of two warring communities. As women reproduce religion's and nation's citizens, the meaning of such an act can be deciphered as follows:

Your women are only good as bodies, and we have used these bodies. These bodies will not reproduce ... Milk is replaced by blood, so that the message is conveyed with utmost clarity: not only will we not allow your community to grow on our side of the border, but we had rather your community did not grow at all. (Subramanian 2013: 100) 
In this sense, women's bodies, viewed by the patriarchal society as passive child-bearing vessels where the active seeds of men are sown to continue one's national/ethnic legacy, are commoditised in a manner that proves fatal to the victims. Moreover, as “women's sexuality symbolises 'manhood;' its desecration is a matter of such shame and dishonour that it has to be avenged" (Menon and Bhasin 1998: 43). Hence, one can claim that the death and mutilation of Ice-candy-man's female relatives are interpreted by him as an attack on his Muslim manhood. This interpretation becomes one of the reasons that instigates the animalistic religious fervour in Ice-candy-man, which leads to his violent act of abducting Ayah.

Another instance that highlights the gruesome tales of violence against women during partition is narrated through Ranna's story. This is the only section in the novel that is narrated through a third person perspective. Ranna is the great-grandson of the cook Imam Din and is about Lenny's age. While the unfolding of violence in the city of Lahore takes predominance in the narrative, Ranna's story exposes the atrocities that occurred in the village of Pir Pindo, thereby revealing the bloodbath of religious hatred in the rural landscape as well. To elaborate, stuck on the wrong side of the border during partition, Ranna's family members are raped, abducted and/or butchered while Ranna escapes alone. Ranna's grandmother panics: "[The Sikhs] are killing all Muslims. Setting fires, looting, parading the Muslim women naked through the streets - raping and mutilating them in the centre of villages and in mosques" (Sidhwa 1988: 207). By destroying the houses of Muslims, Sikhs are metaphorically and literally eliminating the religious Other from the new country. On similar lines, the parading of naked women on the streets, which is aimed at publically shaming and disgracing them, becomes yet another form of insulting the enemy community.

Regarding Ranna's story, Nadia Butt asserts that "Ranna's grim fate symbolises the hideous and gruesome face of nationalism," and "Ranna's misery is a morbid resolution of the partition saga" (2015: 86). Moreover, during his escape, Ranna gets wounded on his head. This physical scar becomes a bodily record of his traumatic experience of partition that fills in the gaps in official history. The narrative proceeds to inform the reader that when Ranna regains consciousness after recuperating from his head injury, he hears "from the direction of the mosque [...] intolerable shrieks and wails of women" (Sidhwa 1988: 202). Furthermore, as Ranna undertakes the journey to Lahore alone, he becomes witness to ghastly sites:

No one minded the semi-naked spectre [of Ranna] as he looked in doors with his knowing, wide-set peasant eyes as men copulated with wailing children - old and young women. He saw a naked woman, her light Kashmiri skin bruised with purple splotches and cuts, hanging head down from a ceiling fan. And looked on with a child's boundless acceptance and curiosity as jeering men set her long hair on fire. He saw babies, snatched from their mothers, smashed against walls ${ }^{13}$ and their howling mothers brutally raped and killed. (Sidhwa 1988: 207)

The above lines reveal that Ranna's story captures an aspect of partition that Lenny's privileged class position protects her from witnessing. Though Lenny does witness acts of violence in Lahore, these instances are mostly singular in nature. Hence, Ranna's experience is invariably different from that of Lenny as it fore-

13 The killing of babies yet again symbolically implies erasing the future of the enemy community. 
grounds the horrific wide-scale nature of hate crimes against women during partition genocide where "sexual abuse, from being one of the weapons of war, became the chief weapon of war" (Punjabi 2012: 233). Bahri describes Ranna's story as "the conduit for a disturbing catalogue of violence against women and children" (1999: 229). While Sidhwa chooses not to tell Ayah's abduction story, through Ranna's story, nonetheless, she describes the gory details of ethnic genocide that accompanied partition.

Another incidence of partition gendered violence is witnessed by Lenny when she sees a fanatic Sikh mob holding aloft a "naked child, twitching on a spear struck between her shoulders, [who] is waved like a flag" (Sidhwa 1988: 134). Here, it is important to note that the impaled child is a female. Hence, as "[t]he female child's naked body takes the place of a flag, a common symbol of nationalist desire," this gesture "emphasiz[es] both the muteness of this feminine body, and the power of the female child's violated shape as a form of communication" (Skinner 2007: 40). In other words, this is indicative of how even a prepubescent female is fatally initiated into violent demonstration of communal nationalism.

\section{The Relevance of the Novel's Title}

The significance of the title of the novel with respect to violence must be noted. In an interview with Preeti Singh, Sidhwa claims that she preferred the original title Ice-Candy-Man because Ice-candy-man is a "pivotal character" who "represents so many of the themes in the novel" (1998: 293). By naming her novel after the most predominant agent of violence in the text, Sidhwa focalises on the terrifying and inhumane aspects of partition, which were played out on women's bodies. However, Sidhwa agrees that Cracking India is a more "appropriate" title for the novel (1998: 293). For instance, in the American title Cracking India, "[t]he metaphors of a cracked body and cracked nation come together to reproduce traumatic events" where "the cracking of a country becomes inextricably associated with [predominantly female] dismembered bodies" (Goel 2015: 25). Moreover, the present continuous tense (cracking) not only suggests that partition witnessed a violent hacking and rupturing of the country, but also indicates that such events persist to have after-effects that are "accompanied by ever deepening scars and widening fissures which continue to fracture new nations long after their inception" (Ray 2000: 132). In fact, the title reflects how the cracking of the nation finds thousands of microcosmic re-enactments of the same in the form of cracking women's bodies by snatching away their dignity through sexual violation. This aspect is further underscored through Lenny's disabled body that "reveals the tensions, conceptual and practical, between the whole and the parts - the nation and its fragments - that existed during Partition and continue to exist today" (Majithia 2015: 11). Here, I assert that if Ayah represents the multi-ethnic undivided India, then Lenny's crippled body "represents the legacy of British colonialism: disease and a disabled South Asia" (Daiya 2008: 79). On similar lines, as it is unlikely for Lenny to fully recover from polio, it can be asserted that Lenny's plagued body, which is symbolic of the nation already damaged by colonial rule, is further cracked and tortured by the event of partition from which she can never recuperate. In effect, the history of a cracked and broken India is inscribed on all mutilated and sabotaged female bodies. 


\section{Conclusion}

For concluding remarks, one can claim that Ice-Candy-Man/Cracking India demonstrates the need to re-examine narratives about women during partition. Ayah's abduction and bodily violation are results of personal jealousy and vehemence of her rejected lover who, as an opportunist, uses the ethnic clash of partition to justify his vindictive actions as a valiant performance of his Muslim nationalism and manhood. Furthermore, Sidhwa, through Hamida, reveals that despite the states' paternalistic efforts to recover and rehabilitate abducted and raped women, these violated women became a reminder of the nations' shame, which led to the social death of the victimised gendered subject. Sidhwa also emphasises the difficulty, or rather, the impossibility of articulating violence against women in its entirety. Sidhwa, through her narrative strategy, underscores that rape narratives can lead to a second violation of the victim. For the surviving victims of sexual violence, articulation is impossible because of the twofold fear of reliving trauma and facing social castigation. In essence, Ice-Candy-Man allows for exposing the patriarchal nationalist agenda at the time of partition that used women's bodies as means of inscribing power relations between two opposing ethnic groups, thereby erasing the gravity of the embodied violence enacted on the female body.

\section{References}

Allen, Jeffner (1986). Lesbian Philosophy: Explorations. Palo Alto: Institute of Lesbian Studies.

Bahri, Deepika (1999). Telling Tales. Interventions 1.2: 217-234. URL: https://www.tandfonline.com/doi/abs/10.1080/13698019900510321. DOI: https://doi.org/10.1080/ 13698019900510321.

Bernard, Anna (2010). Forms of Memory: Partition as a Literary Paradigm. Alif: Journal of Comparative Poetics 30: 9-33. URL: https://www.jstor.org/stable/27929845.

Bharucha, Nilufer E (1994). The Parsi Voice in Recent Indian English Fiction: An Assertion of Ethnic Identity. In Bharucha, Nilufer E. and Vilas Sarang, eds., 73-88.

Bharucha, Nilufer E (1996). From Behind a Fine Veil: A Feminist Reading of Three Parsi Novels. Indian Literature 39.5 (175): 132-141.

Butt, Nadia (2015). Transcultural Memory and Globalised Modernity in Contemporary Indo-English Novels. Berlin: Walter De Gruyter GmbH.

Daiya, Kavita (2002). 'Honourable Resolutions': Gendered Violence, Ethnicity, and the Nation. Alternatives: Global, Local, Political 27.2: 219-247. URL: https://www.jstor.org/ stable/40645046. DOI: https://doi.org/10.1177/030437540202700205.

Daiya, Kavita (2008). Violent Belongings: Partition, Gender, and National Culture in Postcolonial India. Philadelphia: Temple University Press.

Daiya, Kavita (2015). Refugees, Gender, and Secularism in South Asian Literature and Cinema. In Rellstab, Daniel H. and Christiane Schlote, eds., 263-279.

Das, Veena (1995). Critical Events: An Anthropological Perspective on Contemporary India. Delhi: Oxford University Press.

Das, Venna (2006). Life and Words: Violence and the Descent into the Ordinary. Berkeley: University of California.

Didur, Jill (1998). Cracking the Nation: Gender, Minorities, and Agency in Bapsi Sidhwa's "Cracking India". ARIEL: A Review of International English Literature 29.3: 43-64. 
URL: https://journalhosting.ucalgary.ca/index.php/ariel/article/viewFile/34069/28108. DOI: https://doi.org/10.3138/9781442682955-005.

Didur, Jill (2006). Unsettling Partition: Literature, Gender, Memory. Toronto: University of Toronto Press.

Earth (1998). Directed by Deepa Mehta. Eros Entertainment.

Feldman, Allen (1991). Formations of Violence: The Narrative of the Body and Political Terror in Northern Ireland. Chicago: University of Chicago Press.

Franco, Jean (2013). Cruel Modernity. Durham: Duke University Press.

Goel, Gayathri (2015). Reconfiguring the Female Body: Trauma and Sacrifice in South Asian Partition Narratives. MA Thesis. San José: San José State University. URL: https://scholarworks.sjsu.edu/etd_theses/4586/.

Gunne, Sorcha, and Zoë Brigley Thompson (2010). Introduction. In Gunne, Sorcha and Zoë Thompson, eds., 1-20.

Hai, Ambreen (2000). Border Work, Border Trouble: Postcolonial Feminism and the Ayah in Bapsi Sidhwa's Cracking India. MFS Modern Fiction Studies 46.2: 379-426. URL: https://muse.jhu.edu/article/21483. DOI: https://doi.org/10.1353/mfs.2000.0028.

Kabir, Ananya Jahanara (2005). Gender, Memory, Trauma: Women's Novels on the Partition of India. Comparative Studies of South Asia, Africa and the Middle East 25.1: 177190. URL: https://read.dukeupress.edu/cssaame/article-pdf/25/1/177/402901/14-Kabir. pdf. DOI: https://doi.org/10.1215/1089201x-25-1-177.

Kaul, Suvir (2001). Introduction. In Kaul, Suvir, ed., 1-29.

Kleist, Jacquelynn (2011). More Than Victims: Versions of Feminine Power in Bapsi Sidhwa's Cracking India. Pakistaniaat: A Journal of Pakistan Studies 3.2: 69-81. URL: http:// pakistaniaat.org/index.php/pak/article/view/123.

Loomba, Ania (2015). Colonialism/Postcolonialism (3rd ed.). New York: Routledge. DOI: https://doi.org/10.4324/9781315751245.

Majithia, Sheetal (2015). Rethinking Postcolonial Melodrama and Affect. Modern Drama 58.1: 1-24. URL: https://muse.jhu.edu/article/577487. DOI: https://doi.org/10.3138/ md.s84r.1.

Menon, Ritu, and Kamla Bhasin (1998). Borders and Boundaries: Women in India's Partition. New Delhi: Kali for Women.

Mitra, Madhuparna (2008). Contextualizing Ayah's Abduction: Patterns of Violence against Women in Sidhwa's Cracking India. ARIEL: A Review of International English Literature 39.3: 23-44. URL: https://journalhosting.ucalgary.ca/index.php/ariel/article/viewFile/31387/25467.

Mitra, Namrata (2013). Shames Bodies: Partition Violence and Women. In Johnson, Erica L. and Patricia Moran, eds., 197-211.

Muirhead, Lisa (2002). Re-membering Women's Bodies: The Problems of Voice and Representation in Two Partition Narratives. MA Thesis. Winnepeg: University of Manitoba.

Parmar, Prabhjot (2007). Divided Land, Divided Bodies: Representations of Nationalism and Violence in Literature and Films on the Partition of India. PhD Thesis. Ottawa: University of Western Ontario.

Pickup, Francine (2001). Ending Violence against Women: A Challenge for Development and Humanitarian Work. Oxford: Oxfam GB.

Punjabi, Kavita (2012). The Erotics and Politics of Militarization: Communalism and Sexual Violence in Gujarat. In Chatterji, Angana P. and Lubna Nazir Chaudhry, eds., 230-259.

Purohit, Radhika (2012). An Androcentric and Gynocentric Perspective of Women as Victims in Partition Fiction: A Comparative Study. Language in India 12.2: 434-471. 
Rastegar, Kamran (2006). Trauma and Maturation in Women's War Narratives: The Eye of the Mirror and Cracking India. Journal of Middle East Women's Studies 2.3: 22-47. URL: https://read.dukeupress.edu/jmews/article-abstract/2/3/22/15628/Trauma-and-Maturation-in-Women-s-War-Narratives?redirectedFrom=fulltext. DOI: https://doi.org/10.1353/ jmw.2006.0035.

Ray, Sangeeta (2000). En-Gendering India: Woman and Nation in Colonial and Postcolonial Narratives. Durham: Duke University Press.

Roy, Rituparna (2010). South Asian Partition Fiction in English: From Khushwant Singh to Amitav Ghosh. Amsterdam: Amsterdam University Press.

Scarry, Elaine (1985). The Body in Pain: The Making and Unmaking of the World. New York: Oxford University Press.

Sidhwa, Bapsi (1988). Ice-Candy-Man. New Delhi: Penguin India.

Sidhwa, Bapsi (1998). My Place in the World. Interview with Preeti Singh. Alif: Journal of Comparative Poetics 18: 290-298. URL: https://www.jstor.org/stable/pdf/521890.pdf. DOI: https://doi.org/10.2307/521890.

Sidhwa, Bapsi (2008). Defend Yourself against Me. In Shamsie, Muneeza, ed., 27-52. (Original work published 1995)

Skinner, Amy McGuff (2007). Intimate Terror Gender, Domesticity, and Violence in Irish and Indian Novels of Partition. PhD Thesis. Chapel Hill: University of North Carolina at Chapel Hill. URL: https://cdr.lib.unc.edu/indexablecontent/uuid:c21ce98d-7254-49c089af-00241daf86ec.

Stampfl, Tanja (2010). Cracking (Mother) India. In Podnieks, Elizabeth and Andrea O'Reilly, eds., 303-316.

Stokes, Katherine May (2008). Sexual Violence and the Authority to Speak the Representation of Rape in Three Contemporary Novels. MA Thesis. Montréal: McGill University. URL: http://digitool.library.mcgill.ca/thesisfile32521.pdf.

Subramanian, Shreerekha (2013). Women Writing Violence: The Novel and Radical Feminist Imaginaries. New Delhi: SAGE Publications.

Uraizee, Joya (2010). Gazing at the Beast: Describing Mass Murder in Deepa Mehta's Earth and Terry George's Hotel Rwanda. Shofar 28.4: 10-27. URL: https://www.jstor.org/stable/10.5703/shofar.28.4.10. DOI: https://doi.org/10.1353/sho.2010.0044.

Zhao, Peiling (2013). Coping with National Shames through Chinese Women's Bodies: Glorified or Mortified?. In Johnson, Erica L. and Patricia Moran, eds., 179-196. 
